STOVPETS OLEKSANDR,

\title{
CHINESE LEGAL-PHILOSOPHIC SYNCRETISM AND ITS INFLUENCE TO VALUE ORIENTATIONS OF THE CHINESE SOCIETY
}

The article is devoted to researching of historical-cultural and legal-philosophic factors that influence on the formation of value orientations inside the Chinese society. The analysis of these factors was made by using of the historical-philosophical method, which enables to trace the turning points of cultural genesis of Chinese civilization, as well as the specifically-historical approach. The last one contributes to a better understanding of the current status of Chinese socio-cultural reality, in its dependence on the recent past events, and on the Chinese traditional spiritual values. In conclusion it's stated that the essence of actual Chinese approach to regulation of wide-range social relations could be defined as a "legal-philosophic syncretism".

Key words: China; social relations; value orientations; legal-philosophic syncretism; legal policy; mental traditions.

Problem definition. China... We often hear about this country, especially in geopolitical, economic, and historiccultural discourses. But what is the logic of its development? What is its self-position for today? What are Chinese ideals of life? Which prospects does the communication with China open up to other countries, including Ukraine? What kind of categories does China think with? To find some answers to such questions, it is necessary to provide thorough analysis for various spheres of life in China, for different aspects of Chinese modernity and its deep historical roots. In particular, we have to investigate Chinese philosophical traditions (which are based on different ethical, spiritual, and ideological doctrines, first of all Confucianism, Daoism, Buddhism, and legalism), as well as Chinese culture in its diversity, Chinese Marxism (socialism with Chinese characteristics), finally, the Chinese legal system. The last one in many aspects is a consequence and continuation of China's philosophy and culture, reflecting the foundations of Chinese identity - in legal policy, in official ideology, and in the whole social practice of China as a core of a great Sinitic civilization.

Analysis of studies and publications. Chinese worldview, external and internal policy in many forms, and serious socio-economic and legal-organizational changes which are happening in modern China, naturally they are in the focus of numerous humanitarian studies. Mainly, we are talking about philosophical research in the Western scientific community, and those studies which have place in China itself. Among others, we consider as rather illustrative a number of publications, aimed at understanding certain historical-philosophical and politicalcultural aspects of China's evolution, first of all, the problems of Confucian ideology $(H$. Senger, 2004; $P$. Farah, 2008; Loubna El Amine, 2017; Yi-Huah Jiang, 2018; WaiYing Wong, 2019).

Rather informative for this study we also consider some sources, focused on philosophical-economic and legalphilosophic issues concerning today's China (Ya Qin, 2011; W. Lam, 2016; Guang Shen, 2018).

The purpose of this study is to analyze the key historical-cultural and legal-philosophic conditions that make influence to the formation of value orientations for Chinese society.

Presentation of the basic material. The Chinese value system has its own specifics. And its peculiarity is determined by the fact that China has a clear vision of gradually developing Chinese culture. It means that China doesn't think through short-term prospects, and here probably is a secret of its millennial-continuous history. The same approach is also applicable to the sphere of economic life, which has been studied rather detailed in separate sources (Maddison, 2007), and to other realms of being of Chinese socium.

China treats own history tremendously, and evaluates it positively as a whole. The attitude of Chinese historians and philosophers could be synthesized by the following formula: "in China's development there were no critical errors". The similar way of thinking may be applied both to "imperial" and to "socialist" China. The Chinese believe, even Máo Zédōng (毛泽东) was $80 \%$ right in his policy, and only $20 \%$ was mistaken. Let there died between 2040 million of people (Tao Yang, 2008), mainly because of famine, due to his policy of "Great Leap Forward" (大跃进), but that was Máo who laid the foundation for Chinese sovereignty in a new world. It was he who prepared the basic conditions for Dèng Xiăopíng (邓小平). Let us assume, this is a reflection of powerful influence of the Confucian tradition in respect of the ruler's status, which has always been very high in patriarchal China. And this tradition finds a continuation in the development of the People's Republic of China legal system.

The Confucian philosophy influence upon a sphere of Chinese law can be traced in various aspects. Let's try to understand how it looks generally - today's legal system of China? And what is the role of Chinese philosophy of law in relation to the modern being of China's society and state?

Let's begin with the fact that we should separate the notion "China's legal system" and the notion "legal system of the People's Republic of China". These notions have chronological and meaningful differences. It's known the legal system of China belongs to the Far Eastern group of 
law systems, being connected to the ancient legal traditions which partly influence on the formation of modern Chinese legislation. Those traditions have been cultivated for centuries in the bosom of Confucianism, Legalism and some other philosophical flows and schools of Ancient China. From the other side, ideas of "Socialism with Chinese characteristics" and principles of the RomanGerman (continental) law group have been also making their significant impact to the Chinese legal system.

Some Ukrainian researchers of Chinese jurisprudence, including R. Maidanyk, S. Pogrebnyak, O. Skakun, mark a tendency that norms of morality prevail over the norms of law in regulating various issues of social life, calling it an essential distinctive feature of Chinese legal conscience. In particular, R. Maidanyk supposes that the Western tradition, perceived by Chinese law, was supplemented substantially by the legal mentality of the Chinese, especially at the level of individual regulation. Because Chinese legal conscience is held within the traditional Confucian concept for use of law in China, where the last one has usually been playing rather an auxiliary than the main role in the processes of social dialogue. That is why, although the Chinese law really accepted the structure of Roman-German law group, as well as its system of sources, codification principles, and the juridical technique of the latter, however, this reception has proceeded in a modified form, considering the specificity of Confucian ethics (Maidanyk, 2012: 65-73).

Take at least the semantics of the word "law" inside the Chinese and European linguistic space. Chinese etymology of the word "law" (法 "Fă", also 法律 "Fălü") makes us take a look upon the pre-imperial period (until $221 \mathrm{BC}$ ), when it had the meaning of "rule", "lex". D. Bodde, C. Morris prefer to focus on "Fă concept" (法), which meant "fairness", as they think, and in conjunction with "Yì" (義, social justice) might have a meaning of "equal rights" (Bodde, Morris, 1973: 14-15). Along with that, Chinese scientist and translator Yan Fu (严复) warns of possible divergences in Western and Chinese concepts of "law" (Yan Fu, 2014: 139). Thus, the English word "law" which means "rule", "regulated rights and obligations" in Indo-European linguistic discourse, in its Chinese versions may have such translation options as: 1) "order, regulation"; 2) "rights" (commercial interests); 3) "human rights" (innate); 4) "control". It's obvious, all these translation variants have essentially different semantic undertones.

Unlike many other great civilizations, where the written law was respected and mostly appreciated as one that has a divine origin, in China, the law has mainly been considered in rather secular terms. Moreover, its emergence was initially met even slightly hostile by Confucian thinkers who estimated negatively the very fact of existence of such an artificial system of social rules. The necessity of using the law was telling about serious moral decline in society, about violation of the universal cosmic order.

A specific implicit idea of Confucianism is a presumption: the overwhelming majority of humans are good by their nature. Based on such an optimistic view of human potential, Confucius encourages managing by traditional methods supported with social practice and appropriate moral standards. Those one force people to experience a sense of shame for their indecent acts, and to become better not under the pressure of law (and the threats of legal violence) but on the basis of their beliefs and inner conviction. The idea of Confucius asserts that people are capable to accept moral standards of behavior and to undertake adequate measures themselves. This should ultimately lead to a harmonious social order (perhaps, representatives of postnonclassical philosophy could call it "a Confucian version" of the synergetic approach to the public life organization). On the contrary, codified laws require mainly external compliance, and people can actually adhere to such laws, but without fully understanding the true need for the implementation of their regulations. Thus, being embodied in formal laws only, the social order becomes artificial. Besides, it seems to be useless for those citizens who behave themselves in a proper manner.

Here, however, we should clarify that Confucius didn't mean a complete elimination of formal laws. In his opinion, the laws rather should be used minimally, and only in relation to those individuals who chase their selfish interests without any respect to the welfare of the rest of society. At the same time, Confucius calls for an understanding that legal norms are neither absolute nor unchanging over time, but rather fix the social context of a current historical period.

Recognizing that in society different people have various interests, Confucius puts before the ruler a need to coordinate these interests in order to keep public order. But it has to be done by a personal example, not through the dictatorship. Therefore, instead of forcing his subordinates to behave properly, the ruler should show respect and benevolence. The ruler's virtues will make people follow him (Farah, 2008: 221).

Nevertheless, the ruler must have not only the proper ethical qualities, but also the ability to solve the conflicts and problems that the society encounters. And since Confucian ethics determines that people must adhere to moral standards exemplified by their ruler, then the ruler's "quality" determines largely the existing legal-political order. To be objective here, one should also say that among the sinologists there is no absolute consensus in the views on Confucius' personality. Despite the above-mentioned arguments positioning Confucius as an adherent of humanism, there is also another opinion exists among the researchers of Confucian thought: Confucius, who appreciated highly the philanthropy principles, still putted the "ritual" (礼) above "humanism" (仁). In support of this idea, a popular example is given: once Confucius made a death penalty decision in respect of his subordinate who had violated the rules of etiquette while drawing up an official letter to the ruler.

The traditional Confucian paradigm doesn't deny the law, but deeply convinced it's only necessary for those who neglected morality, as well as for obvious criminals, and also for foreigners - as the latter do not understand the ethos of Sinitic civilization at all. But most of the people in China (who themselves are the bearers of Chinese culture ideological values), according to the Confucian concept, are able (and even ought to) do without formal laws. Juridical regulations are considered as an extraordinary, unnatural mechanism for resolving conflicts (within the traditional Confucian paradigm). Laws exist only on potential offenders, while the Confucian ethics pursues such a state of affairs in which there are no grounds for the juridical laws application or the court trials.

Such an ideology was approximately cultivated by Confucianism in the VI-V centuries BC. However, already in the IV-III centuries BC Confucian doctrine faces a rivalry from the side of much more materially-minded system of views on society and the state governance, called Legalism. It was the dominating philosophical school of the Warring States period (Zhànguó 战国时代) in the history of "pre-imperial" China, also known as 法家 "Fă jiā" (School of legalists). The most famous of their representatives is Shang Yang (商鞅), the initiator of reforms that led to the legalization of private land-ownership in some Chinese 
states. The principles of state power centralization, of equality before the Law for everyone (regardless to the social origin and titles) were also settled due to his school.

Unlike the philosophy of Confucius, based on the principles of decency, etiquette in relation to the elders, on the ritual of courtesy (everything that could be expressed with the category 禮 "Li", i.e. the "ceremony", in the literal translation), the ethics of Legalism emphasizes the use of codified laws created and guaranteed by the State, including its right to apply harsh punishments in the interest of public order. The Legalists are guided by the conviction that all people are born selfish, malicious, unbridled and self-interested. In order to heal this "social illness" and make people behave morally, the only effective way (according to Legalists) is to declare clearly defined laws to the public, and to reinforce these laws with strict sanctions.

Shang Yang is an admirer of the doctrine that the "rule of law" is a fundamental principle of strong state power, rather than the ruler's virtues. Representatives of this philosophy believed that severe laws were the only effective mean of managing society and the state. The central idea of Legalism has become "everybody's equality before the Law". Then the understanding has come that state titles should be granted without respect to the social origin, but relatively to real personal abilities and merits. Consequently, any talented person has obtained a potential right to take part in the state affairs management, - as sinologist L. Perelomov marks in his translation of Shang Yang works, named "商鞅书" (Perelomov, 1993).

After the Xinhai Revolution (辛亥革命) in 1911 which resulted the end of existence for the Qing dynasty 大清國, The Republic of China 中華民國 has borrowed main principles of the Roman-Germanic legal system. But in 1949, the establishment of the People's Republic of China (中华人民共和国) led to a reorientation on the Socialist law system, first of all, on the Soviet one. However, later it was also revised and acquired Chinese specifics. At the same time, previous philosophical traditions from the centuriesold history of China retain their influence. The Chinese legal mentality still does not abandon the basic values of Confucianism, but is supplemented by "Socialism with Chinese characteristics" 中国特色社会主义, and simultaneously by Daoist and Buddhist worldview traditions (somewhere at subconscious level). Along with that, such processes as the development of civil society (and Chinese middle class), globalization and geopolitical dominance aspiration - all these factors stimulate further value transformations, which also find their reflection in different areas of Chinese legislation.

It's impossible to cover all the problems of China's legal system development just inside of this study. Therefore we are focusing only on those points that make it possible to show the multi-source character of the Chinese philosophical approach to Law as an instrument of influence upon the national mentality. And if all mentioned above is aimed at illustrating the general mental principles towards law understanding in China, then let's consider some details below. In particular, how today's Chinese government uses legal mechanisms to achieve social justice. Indeed, the category of "justice" appears as one of fundamentals in the value orientations system of any developed society, and the Chinese one is not an exception here. For instance, such phenomena as organized crime (in general) and corruption (which often becomes a part of organized crime) are incompatible with the ideals of social justice neither in the West nor in the East.

One of the vital functions of any state is the law-enforcement, including the fight against organized crime and corruption, which contradict the very essence of the State as a socio-political alliance for the sake of security and collective well-being. Taking into account the population measure of countries, it becomes self-evident the relationship between the law-enforcement activities effectiveness on the one hand, and the national success, stability and security on the other. Especially if the country is as tremendous as China.

Fighting organized crime is a key direction of the lawenforcement policy of contemporary China. The PRC leaders in their program statements emphasize the need for a consistent state response to violation of the existing criminal law. For the beginning, it is necessary to comprehend the meaning of the term "organized crime".

In thesaurus of the United Nations Framework Convention against Organized Crime, an organized crime is a hierarchical group of three or more persons whose activity enables their leaders to make profit, control territories and markets (internal and external) through violence, intimidation or corruption (in particular, by bribing public officials) either for criminal activities itself, or for penetration into the legal economics (UN Framework Convention against Organized Crime, 1997: clause 1).

As a matter of fact, corruption (in many possible forms) is accompanied by penetration into the sphere of legal entrepreneurship (investments in manufacturing, into construction of buildings or infrastructure, into gambling and entertainment, real estate and agricultural enterprises, trading, transportation), in the international financial system (money laundering); participation in tender procedures for various profit-making projects, also by bribing state officials to obtain state contracts for construction, permanent supplying or other services, etc. Corruption often makes a problem for import and export of raw materials and goods of major importance to the economy, using illegal schemes that enable criminals to receive extraprofits, for example, due to inappropriate quality of goods or services, under cover of corruption conspiracies. Naturally, modern Chinese society also faces most of these problems.

By the way, in the modern Chinese history there was a period when the crime level was extremely low. During the reign of Mao Zedong, Chinese society actually didn't know the majority of nowadays crimes such as illegal trafficking of narcotic and psychotropic substances, the legalization of criminal incomes, racketeering, the fraud in real estate and financial sector, etc. In the period of 1953-1978 the number of criminal cases regarding organized crime was decreasing and reached its minimum in the PRC history (Troshchinskiy, 2015: 48).

Mao's era ended in 1976, and since 1978 Chinese society has entered a period of "Reform and Opening-up policy" (改革开放) led by Deng Xiaoping. It was the beginning of profound economic transformations. An increasing liberalization of relations inside the ever-emerging open society in China caused a successful economic development, but simultaneously a critical rise of economic crimes has begun. The PRC has faced new types of criminal acts spreading throughout the country. So, numerous criminal groups and communities have been emerging everywhere. Their goal was getting control over different business sectors. Corruption level has increased significantly among Chinese officials in that period. The banking system has become an instrument of committing crimes in the economic sphere, the problem of tax evasion in large volumes has sharpened, as well as problems of money laundering, capital withdrawal to offshore jurisdictions, and so on (Zhang Qing, 1989).

Thus, start of the "Reform and opening-up policy", being 
corresponded by the weakening of state control over private spheres of social life in China, has stimulated not only rapid economic growth, but also a growing level of economic delinquency. The corruption becomes an inevitable companion of organized crime (Zhenfan Zhang, 1989). All mentioned has put the Chinese legislator before the adoption of appropriate regulatory documents. The most significant for that period has become such rulemaking acts as: the Standing Committee of the PRC National People's Congress decision "On strengthening responsibility of persons who committed crimes that make serious harm to economy" (1982); the NPC Supplementary provisions "On penalties for contraband crimes", "On penalties for corruption and bribery" (1988).

It should be noted, the first time in the new China, the Criminal Code and Criminal Procedural Code were adopted only in 1979. So it was 30 years after the formation of the People's Republic of China. As Chinese lawyers were recognizing, those Codes were rather far from perfection. Some of their norms were extremely uncertain, other ones did not contain fundamental principles of criminal law and criminal procedural law. A lot of legal institutions were missing at that period.

It was during the period of rapid economic development when China's government began to pay special attention to reducing the corruption and economic criminality. In 1982, great Chinese reformer Deng Xiaoping (邓小平) has declared: "Combating economic crimes is the most important guarantee of China's confident movement by a socialist way, and the fulfillment of Four modernizations in the defense industry, agriculture, science, and industrial production... This is an ordinary job. Otherwise, how can we follow the socialist path? If we do not engage in this struggle, then we'll fail in achieving Four modernizations, Opening-up, and the new economic policy in our country" (Deng Xiaoping, 2010: 159). The PRC ex-president Jiang Zemin has stated in September 1997 in the report of CPC XV National Congress (中国共产党第十五次全国代表大会) as follows: "... the fight against corruption is a serious political battle, on which the very existence or downfall of the state depends" (Rénmín ribào, 13.09.1997: 1). Since that time the criminal legislation of the People's Republic of China has undergone an essential evolutionary path.

The valid Criminal Code of the People's Republic of China consists of three parts: General, Special and Supplementary, and contains 452 clauses. There are totally 46 varieties of crimes in which a person can be sentenced to death in China, according to the PRC Criminal Code adopted in 1997. In particular, the death penalty can be applied for such non-violent crimes as "corruption", "fraud with financial instruments and documentation", "counterfeiting of banknotes", "transportation, storage, sale of narcotic substances in large quantities", "contraband of radioactive materials" , "separatism", "state treason" and some others.

Although official statistics still doesn't announce the exact number of persons sentenced to death penalty and executed in China, the estimated figure is up to 5000 people a year. The majority of death penalty executions in PRC are used as a punishment for drug trafficking. The death penalty is not applied in Hong Kong and Macao, which are autonomous jurisdictions in accordance with the principle of "One country, two systems" (国两制). It's known, persons convicted for economic crimes and corruption are usually putted to death by mortal injection, while shot executions are applied against criminals found guilty of murder or drug trafficking. It should be noted, in modern China there's a decrease tendency regarding crimes with the death penalty sanction. However, the liberalization of criminal legislation almost doesn't connect to crimes that contain corruption characters.

In China, widely known is the old stratagem: "Stomp the grass to scare the snake" (打草驚蛇). Applicable to the fight against organized crime, the severe punishment acts as a "stomping the grass" (albeit one person was punished). In aftermath a lot of potential criminals ("scared snakes") may refuse from making crime (Senger, 2004: 289).

Fighting against corruption is regulated by Chapter 8 of the People's Republic of China Criminal Code. The Code provides a highest degree of responsibility (a capital punishment) for corruption crimes, but most often the PRC Supreme People's Court, which makes decision, imposes death penalty with a "two years period execution deferral". During this period, judges and defenders have an opportunity to re-examine all the facts (to exclude a judicial error), while investigators obtain a chance to identify the whole chain of corruption ties of the convicted person. In recent years the PRC legal practice has shown a trend to "soften" a capital punishment for crimes of a corruptive nature, applying the life imprisonment instead, and later it can be reduced to 25 years (Sevalnev, 2014: 93). Since April 2016, in China the death penalty is imposed to corrupt officials whose illegal incomes or bribes exceed 3 million yuan equivalent (approximately 450 thousand US dollars).

The CPC Central Commission on discipline has reported that since 2013, within the framework of Anti-corruption Program implemented by the government of $\mathrm{Xi}$ Jinping (习近平), there has been totally punished around 1.34 million corrupt officials (REUTERS, $8^{\text {th }}$ October 2017). Xi Jinping's campaign against corruption is also known as the "tigers and flies strategy". It is aimed at identifying corruption both among high-ranking state officials (who have "tiger appetites") and among officials working on less important positions, who also overuse their status. After all, successful implementation of mentioned anti-corruption strategy in today's China seems to be the one of juridical preconditions for achievement a greater social fairness, so significant on the way to the "Moderately prosperous society" - Xiăokāng shèhuì (小康社会).

\section{Conclusions}

Value orientations of modern Chinese society may be generally divided in two categories: those which determine the values of spiritual content, and those with material entity. The spiritual-natured value orientations include an attempt to formulate a so-called "Chinese Dream" (中國夢). This is a collective dream related to desire of the Chinese to take back (on China's belief) a sense of national dignity, wounded in the XIX century. However, it seems, this endeavor is not only an ambitious ideologeme, as "The Chinese Dream" also has quite definite economic dimensions: a creation of the "Moderately prosperous society", an overcoming of the disbalance in regional development.

At the mental level, the "Chinese Dream" concept is enhanced among the Chinese people by the feeling of self-sufficiency of their own culture, its continuity, and undeniable dominance over non-Chinese cultures. In Chinese discourse, the very term "culture" has traditionally been used exclusively for designation of Chinese culture (the other ones were considered as "barbarians", deserving a tolerant, even patronizing attitude towards them by the Chinese as the "bearers of culture"). But today this mental tradition is changing. The first reason is that China makes conclusions from its past geopolitical failures, and the next one is more important: right now China is building its own globalization strategy. The latter requires, among other 
things, the construction of a positive image of China in the eyes of the world community, that may be achieved through various "soft power" tools.

Value orientations with a material content include active foreign economic expansion, and China's aspiration to create a science-oriented economy, occupying a high-tech $\&$ intellectual sectors, and leaving other world leaders behind.

Certain historical fragments of the past of China, being studied along with the turning points of Chinese modern history, leads to inference that traditional cultural values (crystallized in Confucian philosophy, in Daoist and Buddhist creeds) today meet the values of a new era. Apparently, it is no coincidence that China's current leader proclaims a reconsidered "Socialism with Chinese Characteristics for a New Era" (习近平新时代中国特色社会主义思想). One of the key principles in the fulfillment of mentioned paradigm is uncompromising systemic struggle against corruption at all levels. The Chinese call this anti-corruption stratagem with an allegorical name "tigers and flies strategy".

However, that is only one of the existing mechanisms aimed at reducing the state power's misuse at various levels of administration in China. The PRC government engrains not only a complex of limitations but also a system of incentives, which generally could be coherenced with the longstanding legal and philosophic traditions of the Sinitic civilization, on the one hand, and on the other, are able to respond adequately to nowadays challenges. Thus, the analysis of the Chinese social practice shows that administrative and other public institutions in modern China use a variety of influence instruments, in order to achieve socially important (nonmaterial and pragmatic) goals. Those instruments are related to different philosophical concepts - Confucianism, Legalism, neo-Marxism, Capitalism, Socialism, etc. Altogether this kind of approach to administrative practice, based on various value orientations and standpoints, may be characterized by a suppositive name "legal-philosophic syncretism". Because the legal conscience of the Chinese is not something mosaic, but appears as one that integrates successfully different outlook traditions, combining them like an inseparable unity.

\section{REFERENCES}

Bodde, D. \& Morris, C. (1973). Law in Imperial China: Exemplified by 190 Ching Dynasty Cases with Historical, Social, and Judicial Commentaries. University of Pennsylvania Press, Philadelphia: 14-15 (In English).

Deng, Xiaoping. (2010). Building a Socialism with a Specifically Chinese Character. Selected Works, Vol. 3 (1982-1992); Beijing: 306 p. (In English).

Farah, P. D. (2008). The Influence of Confucianism on the Construction of the Chinese Political and Juridical System. Identità europea e politiche migratorie. Vita e Pensiero (V\&P), Milano: 193-226 (In Italian; In English).

Fifteenth National Congress of the Communist Party of China. 12-18 September 1997. Rénmín ribào 人民日報．13.09.1997. Archive: 1-3 (In Chinese).

Guang, Shen. (2018). Revision of China's Legislation Law: Towards a More Orderly, Fair and Just Legal System. Hong Kong Law Journal (香港法律杂志). 48 (3): 1137-1158. (In English)

Lam, W. (2016). Xi Jinping's Ideology and Statecraft. Chinese Law \& Government. 48 (6): 409-417. DOI: 10.1080/00094609.2016.1241098. (In English)

Loubna, El Amine. (2017). Classical Confucian political thought: a new interpretation. Princeton University Press, Princeton: 232 p. (In English)

Maddison, A. (2007). Chinese Economic Performance in the
Long Run: 960-2030 AD. OECD, Paris. Retrieved from: http:// piketty.pse.ens.fr/files/Maddison07.pdf (In English)

Maidanyk, R. A. (2012). Civil Law: General Part. Alerta, Kyiv: 472 p. (In Ukrainian).

Perelomov, L. S. (1993). Book of the Ruler of Shang Region (商鞅书); [translation from Chinese]. Ladomir, Moscow: 390 p. (In Russian).

REUTERS. October 8, 2017. Chinese watchdog says 1.34 million officials punished for graft since 2013. Retrieved from: https://www.reuters.com/article/us-china-corruption/chinesewatchdog-says-1-34-million-officials-punished-for-graft-since2013-idUSKBN1CD04B (In English).

Senger, H. (2004). Stratagems. On Chinese art of living and surviving. The famous 36 stratagems over three millennia. Book 1. EKSMO, Moscow: 510 p. (In Russian).

Sevalnev, V. V. (2014). Counteracting the corruption: an experience of the PRC. Journal of Foreign Legislation and Comparative Law. 1: 89-96 (In Russian).

Tao Yang, D. (2008). China's Agricultural Crisis and Famine of 1959-1961: A Survey and Comparison to Soviet Famines. Comparative Economic Studies. 50: 1-29 (In English).

Troshchinskiy, P. V. (2015). Combating crime in China: legalregulatory aspect. The Law Journal. 8: 47-58. DOI: 10.12737/ 12227 (In Russian).

United Nations Framework Convention against Organized Crime. Adopted on July 21, 1997. Retrieved from http:// zakon.rada.gov.ua/laws/show/995_786 (In Ukrainian).

Wai-Ying, Wong (2019). Confucian ethics in Western discourse. Bloomsbury Academic, Sydney: 279 p. (In English).

Ya Qin, J. (2011). Pushing the Limits of Global Governance: Trading Rights, Censorship and WTO Jurisprudence: A Commentary on the China-Publications Case. Chinese Journal of International Law. 10 (2): 271-322. DOI: https://doi.org/10.1093/chinesejil/jmr017 (In English).

Yan, Fu (2014). FăYì (法義). The Spirit of the Laws [Montesquieu, C.; translated from the original French into Chinese \& English, by Yan Fu]. Beijing Times Chinese Paper Bureau, Beijing: 683 p. (In Chinese; In English).

Yi-Huah, Jiang (2018). Confucian Political Theory in Contemporary China. Annual Review of Political Science. 21: 155173 (In English).

Zhang, Qing (1989). The Chinese theory of criminal punishment for economic crimes. Chinese Legal Database, available at: http://www.lawinfochina.com/ (Beijing; Chinese; In English).

Zhenfan, Zhang (1989). Economic crimes and counteracting measures. Chinese Legal Database, available at: http:// www.lawinfochina.com/ (Hebei; In Chinese; In English)

\section{LIST OF REFERENCE LINKS}

Bodde D., Morris C. Law in Imperial China: Exemplified by 190 Ching Dynasty Cases with Historical, Social, and Judicial Commentaries. Philadelphia: University of Pennsylvania Press, 1973. P. $14-15$.

Deng Xiaoping. Building a Socialism with a Specifically Chinese Character. Selected Works, Vol. 3 (1982-1992). Beijing, 2010. 306 p.

Farah P. D. L'influenza della concezione Confuciana sulla costruzione del sistema giuridico e politico Cinese. Identità europea e politiche migratorie. Milano: Vita e Pensiero (V\&P), 2008. P. 193-226.

中国共产党第十五次全国代表大会, 九月 12-18, 1997. Rénmín ribào 人民日報. Archive for 13.09.1997. P. 1-3.

Guang Shen. Revision of China's Legislation Law: Towards a More Orderly, Fair and Just Legal System. Hong Kong Law Journal (香港法律杂志). 48 (3) 2018. Hong Kong. P. 1137-1158.

Lam W. Xi Jinping's Ideology and Statecraft. Chinese Law \& Government. 48 (6) 2016. P. 409-417. DOI: 10.1080/ 00094609.2016 .1241098 . 
Loubna El Amine. Classical Confucian political thought: a new interpretation. Princeton, New Jersey: Princeton University Press, 2017. 232 p.

Maddison A. Chinese Economic Performance in the Long Run: 960-2030 AD. Paris: OECD, 2007. URL: http://piketty.pse.ens.fr/ files/Maddison07.pdf (дата звернення 01.12.2018)

Майданик Р. А. Цивільне право: Загальна частина. Київ: Алерта, 2012. 472 с.

Переломов Л. С. Книга Правителя области Шан ("Шан Цзюнь Шу"; перевод с китайского). М.: Ладомир, 1993. 390 с.

REUTERS. October 8, 2017. Chinese watchdog says 1.34 million officials punished for graft since 2013. URL: https:// www.reuters.com/article/us-china-corruption/chinesewatchdog-says-1-34-million-officials-punished-for-graft-since2013-idUSKBN1CD04B (дата звернення 03.12.2018).

Зенгер Х. Стратагемы. О китайском искусстве жить и выживать. Знаменитые 36 стратагем за три тысячелетия / под общ. ред. В. С. Мясникова; в 2-х томах. Том 1. М.: ЭКСМО, 2004. 510 c.

Севальнев В. В. Противодействие коррупции: опыт КНР Журнал зарубежного законодательства и сравнительного правоведения. 2014. № 1. С. 89-96.

Tao Yang D. China's Agricultural Crisis and Famine of 19591961: A Survey and Comparison to Soviet Famines. Comparative Economic Studies. Vol. 50, 2008. P. 1-29.

Трощинский П. В. Борьба с преступностью в Китае: нор- мативно-правовой аспект. Правовой журнал. 2015. № 8. C. 47-58. DOI: 10.12737/12227.

Рамкова Конвенція Організації Об'єднаних Націй проти організованої злочинності від 21.07.1997 р. Офіційна база законодавства України. URL: http://zakon.rada.gov.ua/laws/show/ 995_786 (дата звернення 02.12.2018).

Wai-Ying Wong. Confucian ethics in Western discourse. Sydney: Bloomsbury Academic, 2019. 279 p.

Ya Qin J. Pushing the Limits of Global Governance: Trading Rights, Censorship and WTO Jurisprudence: A Commentary on the China-Publications Case. Chinese Journal of International Law. 2011, 10 (2). P. 271-322 (DOI: https://doi.org/10.1093/chinesejil/ jmr017).

Yan Fu. FăYì (法義). The Spirit of the Laws [Montesquieu C.; translated from the original French into Chinese \& English, by Yan Fu]. Beijing: Beijing Times Chinese Paper Bureau, 2014. 683 p.

Yi-Huah Jiang. Confucian Political Theory in Contemporary China. Annual Review of Political Science. Vol. 21, 2018. P. 155173.

Zhang Qing. The Chinese theory of criminal punishment for economic crimes. Chinese Legal Database, 1989. URL: http:// www.lawinfochina.com/

Zhenfan Zhang. Economic crimes and counteracting measures. Chinese Legal Database. Hebei, 1989. URL: http:// www.lawinfochina.com/

Стовпець Олександр,

Одеський національний морський університет (Одеса, Украӥна) e-mail: a.stovpets@gmail.com,ORCID0000-0001-8001-4223

\section{КИТАЙСЬКИЙ ФІЛОСОФСЬКО-ПРАВОВИЙ СИНКРЕТИЗМ І ЙОГО ВПЛИВ НА ЦІННІСНІ ОРІЕНТИРИ КИТАЙСЬКОГО СУСПІЛЬСТВА}

Статтю присвячено дослідженню історико-культурних та фрілософсько-правових факторів, які справляють вплив на формування ціннісних орієнтирів китайського суспільства. Аналіз цих факторів проведено із застосуванням історико-філософського методу, який дає змогу простежити поворотні моменти культуроґенезу китайської цивілізації, та конкретно-історичного підходу. Останній сприяє кращому розумінню залежності нинішнього стану китайської соціокультурної реальності від подій недалекого минулого, та від традиційних духовних цінностей, сформованих на різних етапах історичного шляху Синітської цивілізації. Робиться акцент на взаємній детермінованості матеріальної і духовної складової у розвитку китайського соціуму, в якому прагнення до реалізації прагматичних інтересів вдало поєднується із глибокою повагою до власних духовнокультурних традицій, джерелами котрих є конфуціанство, даосизм та, почасти, легізм. Специфріка китайської ментальності, яка багато в чому визначається конфуціанською етикою, віддзеркалюється у національній політико-правовій доктрині, у моделях соціальних відносин, у ставленні сучасних китайців до інститутів держави, права, державної влади, правової політики тощо. У статті підкреслюється, що китайська юриспруденція зазнавала потужного впливу з боку двох філософських доктрин - конфуціанства та легізму, і така ситуація спостерігалася майже протягом усієї історії імперського Китаю. Цим і обґрунтовується виражена тенденція до переважання норм моралі над нормами права у регулюванні різноманітних питань суспільного життя, майже завжди, аж до Синьхайської революції. У XX столітті норми конфуціанської етики і установки легізму, що визначали основи правової системи Китаю, було істотно переглянуто під впливом марксистських ідей, а також внаслідок активної рецепції принципів романо-германської правової системи. Це позначилося на різних областях правозастосовної практики в Китаї, однак для демонстрації тих змін ми обмежилися аналізом проблематики організованої злочинності та протидії корупції в КНР. У висновку констатується, що сутність нинішнього китайського підходу до регулювання широкого кола суспільних відносин може бути визначено як "філософсько-правовий синкретизм". Адже правова свідомість китайців видається не чимось мозаїчним, а постає такою, що успішно інтегрує різні світоглядні традиції, суміщаючи їх у нерозривній єдності.

Ключові слова: Китай; соціальні відносини; ціннісні орієнтири; фрілософрсько-правовий синкретизм; правова політика; ментальні традиції.

(C) Stovpets Oleksandr

Надійшла до редакції: 06.12.2018

Прийнята до друку: 11.02.2019 